\title{
Penerapan Peradilan Adat Berbasis Kuasi Yudisial Dalam Memutus Sengketa Adat
}

\author{
Al Araf Assadallah Marzuki \\ Pusat Penelitian Masyarakat dan Budaya LIPI \\ Gedung Widya Graha LIPI lantai 6 \& 9 Jalan Gatot Subroto No. 10 Jakarta Selatan, Telepon/Fax: +6221 5701232 \\ Correspondence email: al.araf23@gmail.com
}

\begin{abstract}
Abstrak. Peradilan adat bukanlah lembaga yudisial yang dapat memutus suatu sengketa dengan irah-irah keadilan sebagaimana dalam peradilan nasional sehingga pengakuan terhadap keputusan adat tidak mendapatkan kekuatan hukum yang tetap yang mengakibatkan ketidakpastian hukum dalam penyelesaian sengketa melalui lembaga peradilan adat. Maka demikian adapun sebuah gagasan yang ditawarkan dalam penelitian ini yaitu menerapkan peradilan adat sebagai kuasi yudisial dalam memutus sengketa adat. Melalui penelitian yuridis normatif didapat hasil bahwa: pertama, kedudukan peradilan adat hanya sebatas penyelesaian sengketa secara musyawarah, dan dalam hierarki peradilan kedudukannya tidak diakui. Kedua, model kuasi yudisial yang dapat diterapkan dalam peradilan adat dapat mencontoh KPPU dalam memutus sengketa yang dimana untuk mendapatkan kekuatan hukum tetap, putusan KPPU perlu mendapatkan penetapan pengadilan negeri, dan bilamana ada yang keberatan atas putusan tersebut dapat mengajukan upaya hukum keberatan di pengadilan negeri dalam jangka waktu 14 hari sejak diterimanya putusan pada para pihak.
\end{abstract}

Kata kunci: peradilan adat, kuasi yudisial, sengketa adat

Abstract. The customary court is not a judicial institution that can decide a dispute with the direction of justice as in the national court so that recognition of customary decisions does not get permanent legal force which results in legal uncertainty in dispute resolution through customary court institutions. Thus, there is an idea that is offered in this research that implements customary courts as quasi-judicial in resolving customary disputes. Through normative juridical research, it is found that: first, the position of customary courts is only limited to deliberative dispute resolution, and in the judicial hierarchy its position is not recognized. Second, the quasi-judicial model that can be applied in customary courts can emulate KPPU in deciding disputes where to obtain permanent legal force, the KPPU's decision needs to be ruled by a district court, and if some object to the verdict, they can file an objection legal remedy in the domestic court. a period of 14 days from receipt of the decision on the parties.

Keywords: customary courts, quasi-judicial, customary disputes.

\section{PENDAHULUAN}

Pengakuan konstitusional atas keberadaan masyarakat hukum adat (common law community) telah ditetapkan dalam batang tubuh UUD 1945 pasca amandemen, khususnya dalam Pasal 18B ayat (2) yang berbunyi: "Negara mengakui dan menghormati masyarakat hukum adat dan hak tradisionalnya selama masih hidup dan sejahtera sesuai dengan perkembangan masyarakat dan prinsip menurut hukum negara Republik Indonesia Serikat”. Kemudian Pasal 18B ayat 2 UUD 1945 mensyaratkan bahwa pengakuan dan penghormatan terhadap masyarakat hukum adat dan hak tradisionalnya harus diatur dengan undang-undang.

Akan tetapi pengakuan atas keberadaan masyarakat adat dalam banyak hal belum sepenuhnya terlembagakan. Hal ini terlihat dari banyaknya permasalahan yang dihadapi masyarakat adat. Pertama, dilihat dari semua aspek kehidupan (ekonomi, hukum, sosial budaya, dan hak asasi manusia), masyarakat adat selalu berada dalam posisi yang kurang beruntung sebagai minoritas. Kedua, masyarakat adat termarginalkan dalam proses pembangunan karena belum sepenuhnya dikenal karena tanah adat / ulayatnya. Ketiga, masyarakat adat sering kali mengalami konflik antar masyarakat adat, antara masyarakat adat dengan masyarakat adat lainnya, dan antara masyarakat dengan pemerintah. Keempat, dalam menyelesaikan masalah yang berkaitan dengan masyarakat hukum adat, sering terjadi konflik ketika hukum adat bertentangan dengan hukum nasional Indonesia. ${ }^{1}$

Berkenaan dengan penyelesaian sengketa antar masyarakat adat, negara telah memberikan hak kepada masyarakat adat untuk menyelesaikan masalah dengan sistem peradilan adat, yang didasarkan pada Pasal 103 huruf d dan e Undang-Undang Nomor 6 Tahun 2014 tentang Desa. Dalam pasal tersebut menunjukkan bahwa untuk memprioritaskan penyelesaian secara musyawarah, penyelesaian sengketa adat dilakukan berdasarkan hukum adat yang berlaku di Desa Adat dengan mengutamakan prinsip-prinsip hak asasi manusia dengan menyelesaikan secara musyawarah,, serta penyelenggaraan sidang perdamaian peradilan Desa Adat dilakukan sesuai dengan ketentuan

1 Dalam penjelasan umum Rancangan Undang-Undang tentang Masyarakat adat yang di kutip dari dokumen sistem informasi (DOKSILEG) Dewan Perwakilan Rakyat Republik Indonesia. www.dpr.go.id 
peraturan perundang-undangan. berdasarkan ketentuan pasal tersebut, peradilan adat dalam Undang-Undang tentang Desa berfungsi untuk memutus dan mendamaikan sengketa adat berdasarkan hukum adat.

Jika melihat peradilan adat sebagaimana dalam Undang-Undang tentang Desa, keberadaan lembaga peradilan adat diakui dalam kerangka kebijakan, namun dalam praktiknya sering terjadi konflik antar putusan hukum adat yang dikesampingkan dalam peradilan nasional. hal ini dikarenakan peradilan adat bukanlah lembaga yudisial yang dapat memutus suatu sengketa dengan irah-irah keadilan sebagaimana dalam peradilan nasional sehingga pengakuan terhadap keputusan adat tidak mendapatkan kekuatan hukum yang tetap yang mengakibatkan ketidakpastian hukum dalam penyelesaian sengketa melalui lembaga peradilan adat. Oleh karena itu, terdapat ide yang ditawarkan dalam penelitian ini, khususnya untuk menerapkan peradilan adat sebagai kuasi yudisial dalam menyelesaikan sengketa adat.

Kuasi yudisial merupakan lembaga peradilan yang memiliki kewenangan untuk membuat amar putusan dan pertimbangan-pertimbangan hukum yang mengikatkan suatu subjek hukum dengan putusan dan pertimbangan pengadilan serta memberikan sanksi. yang nantinya eksekusi keputusan tersebut dilaksanakan di peradilan Nasional guna mendapatkan kekuatan hukum yang tetap (the power to make binding orders and judgments). ${ }^{2}$ Sebagai contoh lembaga yang menerapkan Kuasi yudisial adalah Komisi Pengawas Persaingan Usaha (KPPU), dalam hal ini KPPU dalam memutus sengketa persaingan usaha tidak sehat hanya memiliki kewenangan untuk memutus tetapi tidak ada kewenangan untuk menegakkan Putusan KPPU itu sendiri yang kewenangan dalam menegakkan putusan tersebut dilimpahkan ke pengadilan negeri guna untuk mendapatkan penetapan pengadilan negeri agar keputusan tersebut memiliki kekuatan hukum tetap, sehingga keputusan tersebut dapat dieksekusi dan pihak yang diputus tunduk kedalam putusan tersebut.

Berdasarkan latar belakang dan permasalahan yang telah digambarkan di atas, permasalahan yang di angkat sebagai pertanyaan penelitian ini adalah apakah penerapan model kuasi yudisial peradilan adat dapat diterapkan dalam memutus sengketa adat di Indonesia, yang mencakup pertanyaan sebagai berikut:

1. Bagaimana kedudukan peradilan adat dalam menyelesaikan sengketa adat sebagai lembaga peradilan di Indonesia?

2. Bagaimana model penerapan kuasi yudisial peradilan adat dalam memutus sengketa adat?

Jenis penelitian yang digunakan adalah penelitian hukum normatif. Penelitian hukum normatif adalah metode penelitian untuk penyelesaian masalah hukum yang biasanya didasarkan pada kajian kritis dan mendalam terhadap bahan pustaka dan dokumen hukum yang berkaitan dengan masalah hukum yang dipelajari. Penelitian ini menggunakan pendekatan perundang-undangan (statute approach) dan perbandingan (comparative approach) ${ }^{3}$. Kajian normatif tentunya perlu menggunakan pendekatan perundang-undangan, karena aspek yang akan dikaji adalah berbagai kebijakan hukum yang menjadi fokus sekaligus tema sentral sebuah kajian. Teknik penelitian yang digunakan adalah deskriptif analisis, karena teknik deskriptif merupakan teknik dasar analisia yang tidak dapat dihindari, artinya deskripsi yang menggambarkan apa adanya dalam suatu situasi atau kedudukan sesuai proposisi hukum.

\section{PEMBAHASAN}

\section{Kedudukan Peradilan Adat Dalam Menyelesaikan Sengketa Adat Sebagai Lembaga Peradilan Di Indonesia}

Pengakuan atas keberadaan masyarakat adat (dan hukum adat) telah menjadi dinamika dalam sejarah hukum Indonesia. Sebelum tahun 1945, pemerintah kolonial Belanda menetapkan sistem hukum yang membagi sistem hukum menjadi tiga bagian, yaitu: hukum perdata barat, hukum untuk negara timur asing, serta hukum adat untuk masyarakat adat dari penduduk asli.

Dalam hukum adat terdapat istilah peradilan adat. Keberadaannya diakui sebelum kemerdekaan Indonesia oleh pemerintah Belanda, yang pada saat itu dikenal dengan lima jenis pengadilan, yaitu Pengadilan Adat (Inheemsche Rechtspraak), Pengadilan Agama (Godsdienstige Rechtspraak), Pengadilan Gubernemen (Gouvernement srechtspraak), Pengadilan Swapraja (Zelfbestuur rechtspraak), dan Pengadilan Desa (Dorpjustitie). ${ }^{4}$

Selama pemerintahan Belanda, sistem peradilan yang berlaku untuk masyarakat pribumi adalah sistem peradilan adat atau desa. Hal ini dikarenakan Belanda merasa tidak bisa menyelesaikan sendiri permasalahan masyarakat Hindia Belanda (Indonesia) dengan menggunakan peradilan Eropa. Oleh karena itu, pemerintah Belanda memandang perlu adanya pembagian kelompok penduduk. Hal ini sesuai dengan Pasal 163 "Instache Staatsregeling" yang mengatur bahwa penduduk Hindia Belanda terbagi menjadi tiga kelompok. yaitu: kelompok penduduk Eropa, kelompok penduduk Timur asing, dan kelompok penduduk pribumi. Ketentuan ini mengatur setiap penduduk dari setiap kelompok harus menerapkan aturan hukum yang sesuai dengan kelasnya. Untuk menegakkan keadilan bagi

2 Muh Risnain, Eksistensi Lembaga Kuasi yudisial dalam Sistem Kekuasaan Kehakiman di Indonesia: Kajian terhadap Komisi Pengawas Persaingan Usaha, Jurnal Hukum dan Peradilan Vol. 3 Edisi 1 Tahun 2014, hlm. 3

${ }^{3}$ Peter Mahmud Marzuki, Penelitian Hukum, (Jakarta: Kencana Prenada Media group), 2007, hlm. 96

${ }^{4}$ Koerniatmanto Soetoprawiro, Pemerintahan dan peradilan Indonesia: asal-usul dan perkembangannya, (Bandung: Citra Aditya Bakti, 1994), hlm. 91-92. 
masyarakat adat yang berada dalam yurisdiksi peradilan, siapa pun dapat menggugat masyarakat adat yang merasa haknya telah dilanggar, tanpa terkecuali kelompok Eropa dan Timur asing juga dapat menggugat kelompok masyarakat adat menggunakan aturan hukum tersebut.

Keadilan yang berlaku saat itu adalah peradilan yang dilakukan oleh hakim-hakim Eropa dan Indonesia bukan atas nama raja atau ratu Belanda maupun atas sistem hukum Eropa, tetapi peradilan dilakukan dan dilaksanakan berdasarkan sistem adat. hukum yang ditetapkan pada residen dengan persetujuan direktur kehakiman Batavia. ${ }^{5}$

Saat ini keberadaan hukum adat diatur oleh peraturan perundang-undangan yang secara eksplisit menyebutkan istilah hukum adat dan menjelaskan konsep peradilan adat yaitu Undang-Undang Nomor 21 Tahun 2001 tentang Otonomi Khusus Papua. Undang-undang tersebut menegaskan pengakuan dan penghormatan negara terhadap pengadilan adat Papua. Berdasarkan Pasal 51 ayat (1) Undang-Undang tersebut, pengadilan adat adalah pengadilan perdamaian dalam masyarakat hukum adat yang berwenang memeriksa dan mengadili sengketa perdata adat dan perkara pidana di antara anggota masyarakat hukum adat yang bersangkutan. Selain itu, pada ayat (2) dan ayat (3) ditetapkan bahwa pengadilan didirikan sesuai dengan ketentuan hukum adat masyarakat hukum adat yang bersangkutan berhak memeriksa dan mengatur sengketa perdata adat dan pidana sesuai dengan hukum adat. Selain Undang-Undang Nomor 21 Tahun 2001, istilah pengadilan adat juga ditemukan dalam tafsir Pasal 9 ayat (1) UndangUndang Nomor 18 Tahun 2004 tentang Perkebunan, yang kenyataannya kesatuan masyarakat adat masih diakui keberadaannya. Menurut Sudanta, dalam Pasal 51 Undang-Undang Nomor 21 Tahun 2001, konsep peradilan adat dijabarkan sebagai berikut: ${ }^{6}$

1. Peradilan adat merupakan sistem peradilan yang hidup selaras dengan lingkungan hukum adat Indonesia;

2. Peradilan adat didasarkan hukum adat;

3. Peradilan adat bukan bagian dari sistem peradilan nasional;

4. Peradilan adat memiliki kewenangan untuk memutuskan masalah adat dalam bentuk sengketa dan pelanggaran hukum adat;

5. Peradilan adat memiliki kekuasaan untuk memutuskan masalah di antara kesatuan masyarakat hukum adat.

Selain itu, Undang-Undang Nomor 6 Tahun 2014 tentang Desa mencantumkan pengakuan peradilan hukum adat. Berdasarkan Undang-Undang tentang Desa tersebut, negara mengakui kekuasaan desa adat untuk menyelesaikan masalah hukum warganya melalui Pasal 103 Huruf d dan e, yang menyatakan bahwa kewenangan desa adat dapat berupa menyelesaikan sengketa adat dengan ketentuan hukum adat, sesuai dengan adat istiadat yang berlaku dimana mengedepankan prinsip-prinsip hak asasi manusia dengan memberikan prioritas untuk menyelesaikan masalah sengketa adat melalui musyawarah, dan melakukan persidangan dengan damai di desa sesuai aturan peraturan perundang-undangan.

Selain undang-undang tentang desa, posisi pengambilan keputusan dalam prosedur penyelesaian sengketa adat juga diakui sebagai sumber yurisdiksi dalam mengambil keputusan oleh hakim. Hal ini berdasarkan Pasal 5 ayat (1) Undang-Undang Nomor 48 Tahun 2009 tentang Kehakiman, yang menjelaskan bahwa hakim dan hakim konstitusi wajib mengkaji nilai-nilai hukum dan rasa keadilan yang hidup dalam masyarakat. Ketentuan tersebut dimaksudkan untuk mengambil keputusan hakim dan hakim konstitusi yang sesuai dengan hukum dan rasa keadilan di masyarakat. Selain itu, putusan pengadilan harus memuat tidak hanya alasan dan dasar putusan, tetapi juga memaut pasal dan peraturan yang relevan atau sumber hukum tidak tertulis sebagai dasar untuk mengadili. Namun secara struktural, pengadilan adat tidak terikat oleh hierarki peradilan yang ditentukan dalam Undang-Undang Nomor 48 Tahun 2009 tentang Kehakiman. Pasalnya, berdasarkan Pasal 18 Undang-Undang Nomor 48 Tahun 2009 tentang kehakiman, kekuasaan kehakiman yang dilakukan oleh sebuah Mahkamah Agung dan badan peradilan yang berada di bawahnya hanya sebatas dalam ruang lingkup peradilan umum, peradilan agama, peradilan militer, peradilan tata usaha negara, dan peradilan di mahkamah Konstitusi.

\section{Model Penerapan kuasi yudisial $l$ Peradilan Adat Dalam Memutus Sengketa Adat}

Dalam praktik dan perkembangan peradilan Indonesia, lembaga peradilan khusus yang secara jelas dan formal disebut sebagai pengadilan hukum telah banyak tumbuh dan berkembang dengan adanya lembaga-lembaga yang dibentuk secara tegas dalam undang-undang. Meskipun lembaga-lembaga ini tidak secara eksplisit merujuk kedalam pendefinisian peradilan, akan tetapi lembaga-lembaga tersebut memiliki kewenangan dan mekanisme kerja seperti lembaga peradilan yang memiliki sifat mengadili. Secara hukum, lembaga-lembaga ini memiliki hak untuk meninjau dan memutuskan perselisihan atau kasus pelanggaran hukum, dan bahkan kasus pelanggaran etika tertentu, dan keputusan yang bersifat final dan mengikat (final and binding) sebagaimana putusan pengadilan yang bersifat

\footnotetext{
${ }^{5}$ Herlambang P. Wiratraman, Perkembangan Politik Hukum Peradilan Adat, Jurnal Mimbar Hukum, Vol. 30 , No.3 Tahun 2018, hlm. 493.

${ }^{6}$ Sudantra, Pengakuan Peradilan Adat dalam Politik Hukum Kekuasaan Kehakiman, (Denpasar: Swasta Nulus, 2016), hlm. 
“inkracht” pada umumnya. Secara umum, semua itu untuk memberikan keadilan atas nama kekuasaan kepada pihakpihak yang terkena dampak dalam pengambilan keputusan.

Oleh karena itu dapat dikatakan bahwa lembaga yang memiliki wewenang untuk 'mengadili' tetapi tidak dapat dikatakan sebagai pengadilan merupakan bentuk dari peradilan kuasi atau semi-persidangan. diantarinya ada yang berbentuk komisi negara, ada pula yang menggunakan istilah badan atau dewan. Lembaga-lembaga ini, di samping bersifat mengadili, tetapi sering kali memiliki fungsi yang bercampur dengan fungsi regulasi dan/atau administratif. Fungsi regulasi dapat dikaitkan dengan fungsi hukum menurut doktrin "trias-politica Mostesquieu", sedangkan fungsi administratif sama dengan fungsi eksekutif. Dengan demikian, dapat dikatakan bahwa lembaga yang memiliki fungsi semi peradilan atau lembaga yang memiliki kewenangan untuk mengadili dapat dikatakan sebagai lembaga yang memiliki fungsi campuran Misalnya, beberapa di antaranya yaitu: ${ }^{7}$

1. Badan Pengawas Pemilihan Umum (Bawaslu)

2. Ombudsman Republik Indonesia (ORI)

3. Komisi Penyiaran Indonesia (KPI)

4. Komisi Informasi Pusat (KIP) dan Komisi Informasi Daerah (KID)

5. Komisi Pengawas Persaingan Usaha (KPPU)

6. Dan lain-lain.

Sebagai contoh, KPPU adalah badan eksekutif yang bertanggung jawab untuk mengawasi praktik persaingan usaha yang tidak sehat. Namun, undang-undang memberikan kewenangan kepada lembaga persaingan usaha tersebut untuk bertindak sebagai perantara dan pengambil keputusan dalam menyelesaikan perselisihan persaingan usaha tidak sehat. Pembentukan lembaga ini mencerminkan adanya kebutuhan yang sangat mendesak untuk mengendalikan sistem perekonomian Indonesia yang berkembang secara mandiri dan terbuka sebagai akibat dari kebijakan ekonomi yang diterapkan, sehingga mekanisme pengawasan yang paling efektif terhadap berbagai bentuk persaingan usaha tidak sehat dengan membangun infrastruktur kelembagaan yang memiliki kewenangan semi yudisial.

Untuk menggambarkan proses lembaga kuasi peradilan dalam menyelesaikan perselisihan, kita dapat mengambil contoh lembaga peradilan kuasi yang dilakukan oleh KPPU. Peradilan tersebut lahir dan didirikan sesuai dengan amanat Undang-Undang Nomor 5 Tahun 1999 tentang Larangan Praktik Monopoli dan Persaingan usaha Tidak sehat. Dalam ketentuan undang-undang tersebut, negara memberikan tiga kewenangan kepada lembaga tersebut untuk menyelesaikan sengketa, yaitu:

Pertama, kewenangan melakukan penyelidikan, hal ini sebagaimana dalam Pasal 36 huruf (a), (b), (c) dan (d) Undang-Undang Nomor 5 Tahun 1999 tentang Larangan Praktik Monopoli dan Persaingan usaha Tidak sehat yang memberikan kewenangan KPPU untuk :

1. Menerima laporan dari masyarakat dan/atau pelaku usaha tentang dugaan adanya praktik monopoli dan/atau persaingan usaha tidak sehat.

2. Penelitian terhadap adanya dugaan kegiatan usaha dan/atau perilaku usaha yang dapat mengakibatkan terjadinya praktik monopoli dan/atau persaingan usaha tidak sehat.

3. Menyelidiki atau menyelidiki kasus-kasus praktik monopoli dan/atau persaingan usaha tidak sehat yang dilaporkan oleh publik atau pelaku usaha atau yang ditemukan oleh komisi.

4. Melakukan investigasi dan/atau hasil pemeriksaan terhadap ditemukan atau tidak ditemukannya praktik monopoli dan/atau persaingan usaha tidak sehat

Kedua, kewenangan untuk melakukan penuntutan kepada pelaku usaha. Hal ini sebagaimana dalam Pasal 36 huruf (e),(f),(g),(h),(i) Undang-Undang Nomor 5 Tahun 1999 tentang Larangan Praktik Monopoli dan Persaingan usaha Tidak sehat yang menyebutkan: Memanggil pelaku usaha yang diduga telah melanggar ketentuan undangundang persaingan usaha.

1. Memanggil dan menghadirkan saksi, saksi ahli dan setiap orang yang dianggap mengetahui pelanggaran tersebut.

2. Meminta bantuan penyidik dalam menghadirkan pelaku usaha, saksi, saksi ahli, atau siapa pun yang disebutkan dalam undang-undang persaingan usaha. Pihak yang tidak bersedia untuk memenuhi panggilan komisi,

3. Meminta informasi kepada instansi pemerintah terkait penyidikan dan/atau pemeriksaan terhadap pelaku usaha yang diduga melanggar ketentuan undang-undang persaingan usaha.

4. Memperoleh, menyelidiki dan menilai surat, dokumen-dokumen, atau bukti lain untuk penyelidikan dan/atau penyidikan.

Ketiga, kewenangan yudisial, merupakan kewenangan untuk menjatuhkan sanksi kepada pelaku usaha yang melanggar undang-undang persaingan usaha. Kekuasaan KPPU merupakan kewenangan khusus dan super yang

7 Jimly Asshiddiqie, Putih hitam Pengadilan Khusus, (Jakarta: Pusat Analis dan Layanan Informasi Sekretariat Jenderal Komisi Yudisial, 2013), hlm. 13. 
diberikan undang-undang kepada KPPU, hal ini dikarenakan KPPU diberi kewenangan untuk menjatuhkan sanksi kepada pelaku usaha yang melanggar undang-undang persaingan usaha yaitu berupa tindakan administratif. ${ }^{8}$ Akan tetapi sanksi yang diberikan tidak dapat dieksekusi sebelum dimintakan penetapan pengadilan di pengadilan negeri, hal ini dikarenakan KPPU bukanlah lembaga peradilan yang memiliki kekuatan eksekutorial, melainkan lembaga yang memiliki sifat untuk mengadili.

Kemudian berdasarkan Pasal 44 Undang-Undang Persaingan Usaha disebutkan bahwa apabila pelaku usaha keberatan atas putusan yang dilakukan oleh KPPU, maka pelaku usaha tersebut dapat mengajukan keberatan kepada Pengadilan Negeri selambat-lambatnya 14 (empat belas) hari setelah menerima pemberitahuan putusan tersebut, dan apabila Pelaku usaha yang tidak mengajukan keberatan dalam jangka waktu sebagaimana dimaksud dianggap menerima putusan Komisi.

Bilamana kuasi yudisial diterapkan dalam peradilan adat yang mengambil referensi peradilan yang dilakukan oleh KPPU, maka adapun gambaran kecil dari peradilan tersebut yaitu dengan memberikan kewenangan kepada peradilan adat untuk memutus sengketa adat dan eksekusi terhadap keputusan adat tersebut diserahkan kepada pengadilan negeri untuk mendapatkan penetapan sehingga memiliki kekuatan hukum tetap. Bilamana dalam waktu 14 hari sejak mendapatkan penetapan pengadilan negeri tidak ada yang mengajukan upaya hukum keberatan maka putusan peradilan tersebut di anggap telah memiliki kekuatan hukum tetap, akan tetapi bilamana dalam waktu 14 hari sejak penetapan pengadilan negeri ditetapkan, terdapat salah satu pihak tidak puas dengan keputusan, pihak tersebut dapat mengajukan upaya hukum keberatan (banding) ke pengadilan negeri.

Untuk menentukan apakah lembaga peradilan adat dapat menerapkan kuasi peradilan atau tidak, Jimly Assidiqie mengutip pertimbangan putusan Pengadilan Texas dalam kasus Perdue, Brackett, Flores, Utt \& Burns versus Linebarger, Goggan, Blair, kemudian Jimly membagi kriteria peradilan kuasi menjadi enam, yaitu: ${ }^{9}$

1. Kewenangan untuk memberikan penilaian dan pertimbangan. (The power to exercise judgement and discretion);

2. Kewenangan untuk mendengarkan dan menentukan atau mengkonfirmasi fakta dan membuat keputusan. (The power to hear and determine or to ascertain facts and decide);

3. Kewenangan untuk membuat keputusan dan penilaian yang berkaitan dengan subjek hukum dengan pertimbangan dan pertimbangan yang terkandung di dalamnya. (The power to make binding orders and judgements);

4. Kewenangan untuk mempengaruhi hak subjek hukum atau hak milik individu. (The power to affect the personal or property rights of private persons);

5. Kewenangan untuk menyelidiki saksi, memaksa saksi untuk hadir, dan mendengarkan perselisihan saat disidangkan(The power to examine witnesses, to compel the attendance of witnesses, and to hear the litigation of issues on a hearing);

6. kewenangan untuk menegakkan keputusan atau menjatuhkan sanksi. (The power to enforce decisions or impose penalties).

Dari kriteria tersebut, untuk menentukan apakah peradilan adat dapat menerapkan peradilan kuasi dapat dilihat dari uraian sebagai berikut yaitu berdasarkan data penelitian yang dilakukan oleh Sri Yanaurti, dkk, dalam judul buku "Model Capacity Building Kelembagaan Pemerintah dan Masyarakat Untuk Pengelolaan Konflik di Maluku", ada hal yang menarik untuk menerapkan peradilan adat berbasis kuasi yang dimana dalam menyelesaikan sengketa adat, peradilan adat di maluku telah menerapkan model dimana dalam hal terjadi sengketa adat dan dalam proses musyawarah peradilan adat, bilamana terdapat sengketa konflik bisa mengajukan upaya hukum penyelesaian secara damai di lembaga MPMD negeri, dan bilamana tercapai kesepakatan maka akta perjanjian atau kesepakatan perdamaian yang dibuat dalam peradilan adat diregistrasi ke pengadilan negara (pengadilan negeri yang ada di kabupaten/kota) pada periode yang akan ditentukan setelah 10 hari sejak diakta dibuat dan para pihak yang bersengketa menerima isi keputusan tersebut. Akan tetapi jika ada pelanggaran pada akta kesepakatan ini maka proses selanjutnya diselesaikan di pengadilan negara (pengadilan negeri Kabupaten dan Kota). ${ }^{10}$

Sebagai contoh untuk kasus sengketa yang terjadi yaitu sengketa perbatasan tanah, langkah pertama yang harus dilakukan oleh para pihak yang bersengketa adalah melaporkan persoalan yang dialami kepada kepala negeri/ohoi/ratschap (raja). laporan tersebut dituangkan secara tertulis ke dalam sebuah formulir keluhan (komplain), dalam hal Mengisi formulir ini pihak yang menurut penggugat dibantu oleh petugas pencatat perkara (yang di tunjuk negeri/ohoi/ratschap Atau bisa juga ditunjuk pegawai yang khusus bertugas untuk itu oleh pengadilan formal). Setelah menerima laporan dari penggugat tersebut, dalam waktu tertentu, sejak hari pelaporan, kepala negeri/ohoi/ratschap mengundang penggugat dan pihak yang dikomplain (tergugat) untuk hadir dalam acara hiring

${ }^{8}$ Ridwan, Tiga Dimensi Hukum Administrasi Negara dan Peradilan Administrasi Negara, (Yogyakarta: FH UII Press, 2009), hlm.146.

${ }_{9}^{9}$ Jimly Asshiddiqie, op.cit. hlm. 17.

${ }^{10}$ Sri Yanuarti, Model Capacity Building Kelembagaan Pemerintah dan Masyarakat Untuk Pengelolaan Konflik di Maluku, (Jakarta: LIPI Press, 2008), hlm. 158-160 
kasus. Sebagai catatan, pada tingkatan ini Raja ini berfungsi sebagai mediator, dan oleh karena itu ia tidak memiliki kapasitas untuk menyelesaikan kasus ini, tapi fungsinya hanya membantu para pihak yang bersengketa negara yang berkonflik untuk mencari penyelesaian persoalan di antara mereka. jika kedua pihak hadir, maka mediator harus mendorong para pihak untuk bersama-sama mencari jalan keluar dan mencapai kesepakatan. kesepakatan yang tercapai dituangkan dalam akta perjanjian perdamaian. akta ini memiliki kekuatan hukum tetap setelah 10 hari disepakatinya perjanjian perdamaian tersebut. salinan dari akta ini kemudian didaftarkan ke pengadilan negara (pengadilan negeri Kabupaten/Kota) dalam jangka waktu 6 bulan setelah periode tersebut atau untuk wilayah-wilayah yang terpencil, pendaftaran akta perdamaian ke Pengadilan Negeri bisa dilakukan secara periodik pada bulan-bulan tertentu yang akan ditentukan kemudian. ${ }^{11}$

Persoalan yang menjadi dasar dalam penyelesaian sengketa adat di Kepulauan Maluku tersebut adalah sifat dari akta perjanjian perdamaian tersebut hanya diregistrasi di pengadilan negeri, sama halnya seperti akta pendirian badan usaha bukan berbadan hukum yang hanya di daftarkan di pengadilan negeri (sebelum pendaftaran badan usaha bukan berbadan hukum di ambil alih dirjen AHU), akan tetapi bilamana terjadi sengketa atas akta tersebut, para pihak yang berselisih dapat mengajukan gugatan ke pengadilan yang di tunjuk dalam akta tersebut. Artinya akta perjanjian yang dibuat meskipun sudah diregistrasi belumlah memiliki kekuatan hukum yang tetap selama masih ada para pihak yang berselisih akibat dari akta tersebut. Maka dengan demikian untuk mengatasi persoalan tersebut, diperlukannya sebuah model kuasi yudisial dalam memutus sengketa adat yang nantinya diharapkan hasil dari keputusan adat tersebut dijadikan bahan untuk mengajukan penetapan pengadilan di pengadilan negeri di wilayah yurisdiksinya sehingga dengan adanya penetapan ini kekuatan putusan hukum adat dapat diakui dan tidak lagi terjadi gugatan ulang yang dilakukan oleh pihak yang beritikad tidak baik dalam menyelesaikan permasalahan sengketa adat. Kemudian bilamana para pihak keberatan atas putusan peradilan adat yang sudah mendapatkan penetapan pengadilan negeri, maka pihak yang belum puas atas putusan tersebut dapat mengajukan upaya hukum keberatan di pengadilan negeri dalam waktu 14 hari sejak putusan tersebut diberitahukan kepada para pihak yang bersengketa, dan bilamana dalam waktu 14 (empat belas) hari tersebut pihak yang diputus bersalah tidak mengajukan upaya hukum keberatan, maka putusan peradilan adat tersebut dianggap telah memiliki kekuatan hukum tetap.

\section{SIMPULAN}

Dari apa yang telah diuraikan dalam pembahasan diatas, adapun kesimpulan didapat yaitu:

Pertama, Kedudukan peradilan adat dalam menyelesaikan sengketa adat sebagai lembaga peradilan di Indonesia adalah hanya sebatas penyelesaian yang dilakukan secara musyawarah, peradilan adat tidak terikat dalam hierarki peradilan sebagaimana diatur dalam Undang-Undang Nomor 48 Tahun 2009 tentang Kekuasaan Kehakiman, hal ini dikarenakan bahwa berdasarkan Pasal 18 Undang-Undang Nomor 48 Tahun 2009 tentang Kekuasaan Kehakiman membatasi kekuasaan kehakiman yang dilakukan oleh sebuah Mahkamah Agung dan badan peradilan yang berada di bawahnya hanya sebatas dalam ruang lingkup peradilan umum, lingkungan peradilan agama, lingkungan peradilan militer, lingkungan peradilan tata usaha negara, dan oleh sebuah Mahkamah Konstitusi. akan tetapi keberadaannya diakui dan dihormat oleh negara sebagaimana diatur dalam Pasal 103 Huruf d dan e UndangUndang Nomor 6 Tahun 2014 tentang Desa dan Pasal 9 ayat (1) Undang-undang Nomor 18 Tahun 2004 tentang Perkebunan.

Kedua, terkait dengan model penerapan kuasi yudisial peradilan adat dalam memutus sengketa adat yaitu dengan menerapkan peradilan adat berbasis semi peradilan seperti yang dilakukan oleh KPPU dalam memutus sengketa dimana dalam putusan KPPU masih memerlukan Penetapan pengadilan negeri untuk mendapatkan kekuatan hukum tetap, dan bilamana pihak yang dirugikan dapat mengajukan upaya hukum keberatan di pengadilan negeri dalam waktu 14 (empat belas) hari sejak diterimanya putusan tersebut.

\section{DAFTAR PUSTAKA}

\section{Peraturan Perundang-Undangan}

Undang-Undang Dasar Negara Republik Indonesia Tahun 1945.

Undang-Undang Nomor 30 Tahun 1999 tentang Arbitrase dan Alternatif Penyelesaian Sengketa.

UndangUndang Nomor 21 Tahun 2001 tentang Otonomi Khusus Bagi Papua.

Undang-Undang Nomor 48 Tahun 2009 tentang Kekuasaan Kehakiman.

Undang-Undang Nomor 5 Tahun 1999 Tentang Larangan Praktek Monopoli Dan Persaingan Usaha Tidak Sehat Dengan Rahmat Tuhan Yang Maha Esa.

Undang-Undang Nomor 6 Tahun 2014 tentang Desa.

Rancangan Undang-Undang tentang Masyarakat adat yang di kutip dari dokumen sistem informasi (DOKSILEG) Dewan Perwakilan Rakyat Republik Indonesia. www.dpr.go.id. 


\section{Buku}

Amirudin dan Zainal Asikin, 2004, Pengantar Metode Penelitan Hukum, Jakarta: Rajagrafindo Persada.

Jimly Asshiddiqie, 2013, Putih hitam Pengadilan Khusus, Jakarta: Pusat Analis dan Layanan Informasi Sekretariat Jenderal Komisi Yudisial.

Koerniatmanto Soetoprawiro, 1994, Pemerintahan dan peradilan Indonesia : asal-usul dan perkembangannya, Bandung: Citra Aditya Bakti.

Peter Mahmud Marzuki, 2007, Penelitian Hukum, Jakarta: Kencana Prenada Media group.

Ridwan, 2009, Tiga Dimensi Hukum Administrasi Negara dan Peradilan Administrasi Negara, Yogyakarta: FH UII Press.

Sri Yanuarti, 2008, Model Capacity Building Kelembagaan Pemerintah dan Masyarakat Untuk Pengelolaan Konflik di Maluku, Jakarta: LIPI Press.

Sudantra, 2016, Pengakuan Peradilan Adat dalam Politik Hukum Kekuasaan Kehakiman, Denpasar: Swasta Nulus

\section{Jurnal}

Herlambang P. Wiratraman, Perkembangan Politik Hukum Peradilan Adat, Jurnal Mimbar Hukum, Vol 30 , No.3 (2018)

Muh Risnain, 2014, Eksistensi Lembaga Quasi judicial dalam Sistem Kekuasaan Kehakiman di Indonesia: Kajian terhadap Komisi Pengawas Persaingan Usaha, Jurnal Hukum dan Peradilan Vol. 3 Edisi 1 Tahun 2014 